Vantage: Journal of Thematic Analysis

ISSN: 2582-7391

A Multidisciplinary Publication of Centre for Research,

Maitreyi College, University of Delhi

October 2021, Volume 2, Issue 2

Review Article

\title{
Bibliometric Analysis of Peer Reviewed Literature on Sustainable Agriculture Research - Challenges and Prospects
}

\author{
Rashmi Sharma ${ }^{1}$ and Rama Sisodia ${ }^{2 *}$ \\ ${ }^{1}$ Acharya Narendra Dev College, University of Delhi, New Delhi, 110019 \\ ${ }^{2}$ Maitreyi College, University of Delhi, New Delhi, 110021 \\ *Correspondence: $\underline{\text { rsisodia@maitreyi.du.ac.in }}$
}

\begin{abstract}
With the need to fulfil the rising food demands of the increasing population, the agriculture sector faces a huge challenge. The issue is compounded by climatic change, severe shortage of water, increasing salinity, habitat vulnerability and pollution amongst others. Considerable emphasis worldwide is focused on research aimed to sustain as well increase agricultural productivity. The present study focuses on systematically mapping the thrust areas of research related to sustainable agriculture based on search results from SCOPUS database. The retrieved data was analysed using VOS viewer application program to create network maps based on term co-occurrence analysis. The analysis further provides insight into the most active authors, countries, institutions as well as citations. A total of 12,261 documents were retrieved. A significant increase in the number of publications was seen in the last decade. The retrieved documents were contributed by authors belonging to 156 countries and had an average of 6.24 citations per document with an $h$-index of 40 . Cluster analysis highlighted three focus areas of research- (1) sustainable agriculture (2) factors affecting crop yield and (3) basic research into plant growth, metabolism, development and aging. The underlying principle of all the research programs pertain to the use of innovative technologies and judicious use of resources for maximal production with due importance to environmental, economic and social aspects.
\end{abstract}


Keywords: Sustainable agriculture, Bibliometric analysis, Research themes, SCOPUS

\section{INTRODUCTION}

Climate change, increasing population, and the need for providing food security have been matters of concern, driving research worldwide to develop crops and adopting tools and technologies ensuring crop productivity (Fróna et al., 2019; Peter et al., 2020; Tian et al., 2021). However, the need to produce food sustainably is important so as to meet the challenge of rising threat to land, water, and biodiversity (Knickel et al., 2017; Mockshell \& Kamanda, 2018). There is a need for a comprehensive evaluation of areas of research in the context of sustainable agriculture which can provide an overview of the challenges and thrust areas that require attention. The present study aims to analyze the global research activity in agriculture keeping in view the aspect of sustainability, published in peer-reviewed publications from 1979 to 2021. The analysis is based on bibliometrics- a statistical method that quantitatively analyse the research papers related to a specific topic (Donthu et al., 2021). The approach used in the present study is based on data mining terms from scientific journals listed in the SCOPUS database. The SCOPUS database is one of the largest abstract and citation databases of peer-reviewed literature that also has built-in analysis tools and can also generate representative figures (Baas et al., 2020). The analysis includes the nature of documents, years of publication, source, subject area, major journals, active authors, institutions, countries, keyword frequencies, and citation analysis. A number of bibliometric reviews on various aspects of sustainable agriculture have recently been published. Rocchi et al., (2020) focus on the ecological modernization approach to address sustainability in agricultural systems, while Sweileh (2020) has analyzed literature pertaining to food security in the context of climate change. These studies have stressed the need for harnessing adaptive technologies and innovative solutions. The exact themes and research profiles that are being investigated have not been elucidated in detail. Our study aims to provide a macroscopic view of research areas related to sustainable agriculture that can stimulate future research directions.

\section{MATERIAL AND METHODS}

Vantage: Journal of Thematic Analysis, 2021; 2(2): 1-22 
The study was conducted using the SCOPUS database which is one of the most comprehensive database that offers wide coverage in keyword searching and citation analysis and has been frequently used in bibliometric studies (Lv et al., 2021; Pan et al., 2021). The data between 1979 to 2021 was downloaded from SCOPUS for analysis using the search query "Sustainable Agriculture". The date of retrieval was $21^{\text {st }}$ July 2021. The downloaded search results contained full literature data such as document type, year of publication, title, author, keywords, abstract, references, funding agency, citations. The search was restricted to articles and journals related to the subject areaagriculture and biological sciences. The details of search query: (TITLE-ABS-KEY ("Sustainable agriculture") AND ( LIMIT-TO ( PUBYEAR,2021) OR LIMIT-TO ( PUBYEAR,2020) OR LIMIT-TO ( PUBYEAR,2019) OR LIMIT-TO ( PUBYEAR,2018) OR LIMIT-TO ( PUBYEAR,2017) ) AND ( LIMIT-TO ( DOCTYPE,"ar" ) ) AND ( LIMIT-TO ( SUBJAREA,"AGRI" ) ) AND ( LIMIT-TO ( SRCTYPE,"j" )) ). 12,261 articles were retrieved and analyzed. For finding out the current thrust areas of research the search was further restricted to the period of the last five years i.e. between 2017 to 2021 retrieving 1812 articles. The information was downloaded as .csv file and imported into VOSviewer 1.6.16 application software (The Center for Science and Technology Studies, Netherlands; van Eck \& Waltman 2010) for creating two-dimensional co-occurrence maps based on keywords. The normalization method was based on association strength. The node size of each keyword represented the frequency of occurrence of the keyword in the retrieved documents. A higher frequency of occurrence was indicated by a larger node size. The impact of publications was measured using the Hirsch -index ( $h$-index) which is based on citations of publications.

\section{RESULTS AND DISCUSSION}

\subsection{Publication Trend Overview}

The number of publications showed an increasing trend from 1989 (Figure 1) onwards and the highest number of documents were published in 2020 (1413). The realization that sustainable food production would entail environmental protection was made early 
on, during the 1980s. The excessive use of synthetic fertilizers and pesticides was contaminating the groundwater and the exposure of humans through drinking water was a matter of concern (Hallberg, 1987). Application of principles of sustainable agriculture, adopting integrated systems of agriculture production that required lesser input of fertilizers and pesticides and instead of increasing the usage of plant, animal organic water matter for manuring and other conservative agricultural practices was found to be successful (Edwards, 1987). The early eighties also witnessed the beginning of research into biotechnology, aiming to produce herbicide resistance plants (Bunders, 1988). Till about 1991 the number of publications remained below 100 documents per year. A considerable increase in publications was seen after 2010 with the highest growth rate of 30 percent observed from 2019 to 2020 .

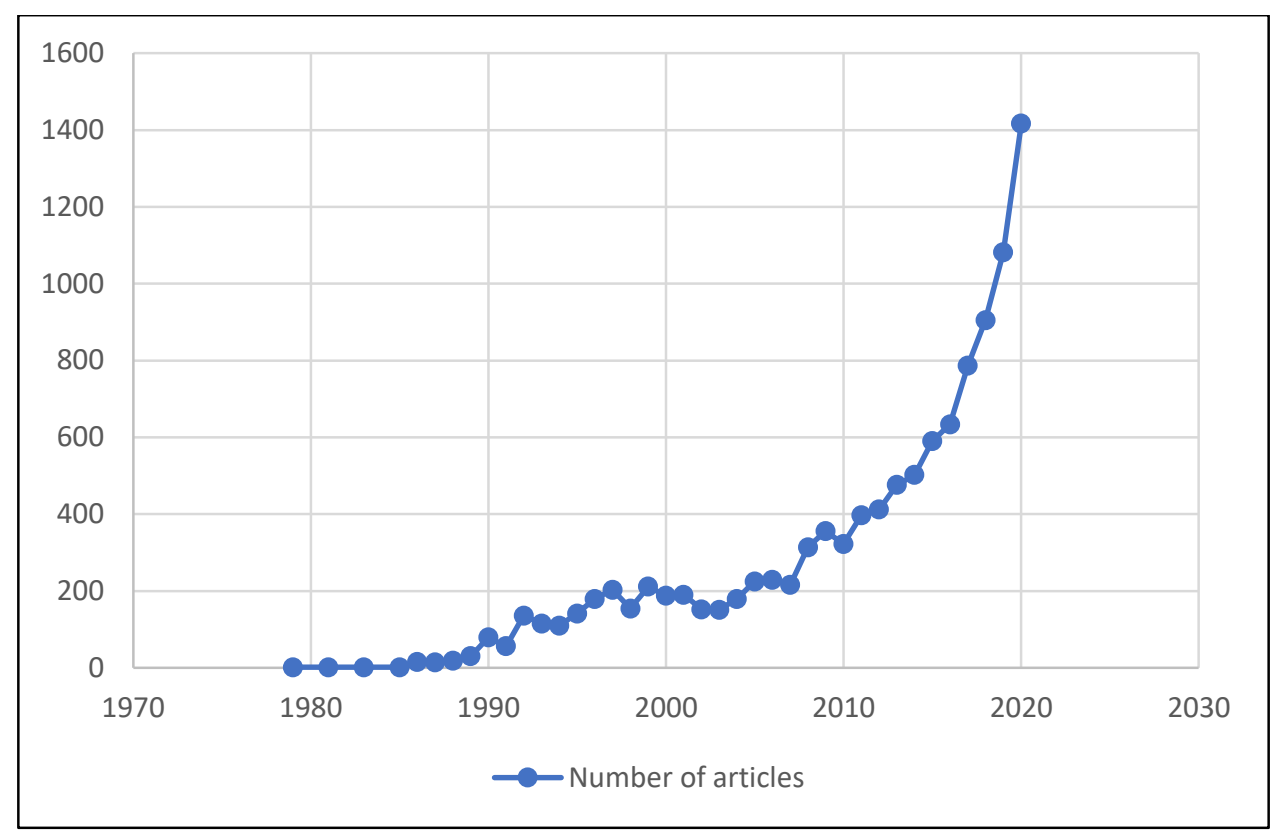

Figure 1: Annual growth of publications in focus area of sustainable agriculture (1979-2020). The year 2021 was excluded since it was ongoing year during the preparation of the manuscript.

\subsection{Types of documents retrieved}

12,261 documents were retrieved using the search query "Sustainable Agriculture". Figures $2 \mathrm{~A}$ and B show the types of articles retrieved and the subject areas under which 
they were indexed. The majority of articles retrieved were research articles (8327; $67.5 \%)$ followed by review articles $(1447 ; 11.7 \%)$, book chapters (1106; 9.0\%), conference papers $(851 ; 6.9 \%)$, books $(191 ; 1.5 \%)$, editorials $(148 ; 1.2 \%)$, notes $(121$; $1 \%)$, short surveys $(46 ; 0.4 \%)$, letters $(36 ; 0.3 \%)$, conference reviews $(32 ; 0.3 \%)$. All the articles retrieved were in the English language. Most of the documents were indexed under the subject area of agricultural and biological sciences $(6780 ; 29.7 \%)$ followed by environmental sciences $(4513 ; 19.8 \%)$, social sciences $(2069 ; 9.1 \%)$, biochemistry, genetics, and molecular biology $(1595 ; 7 \%)$.
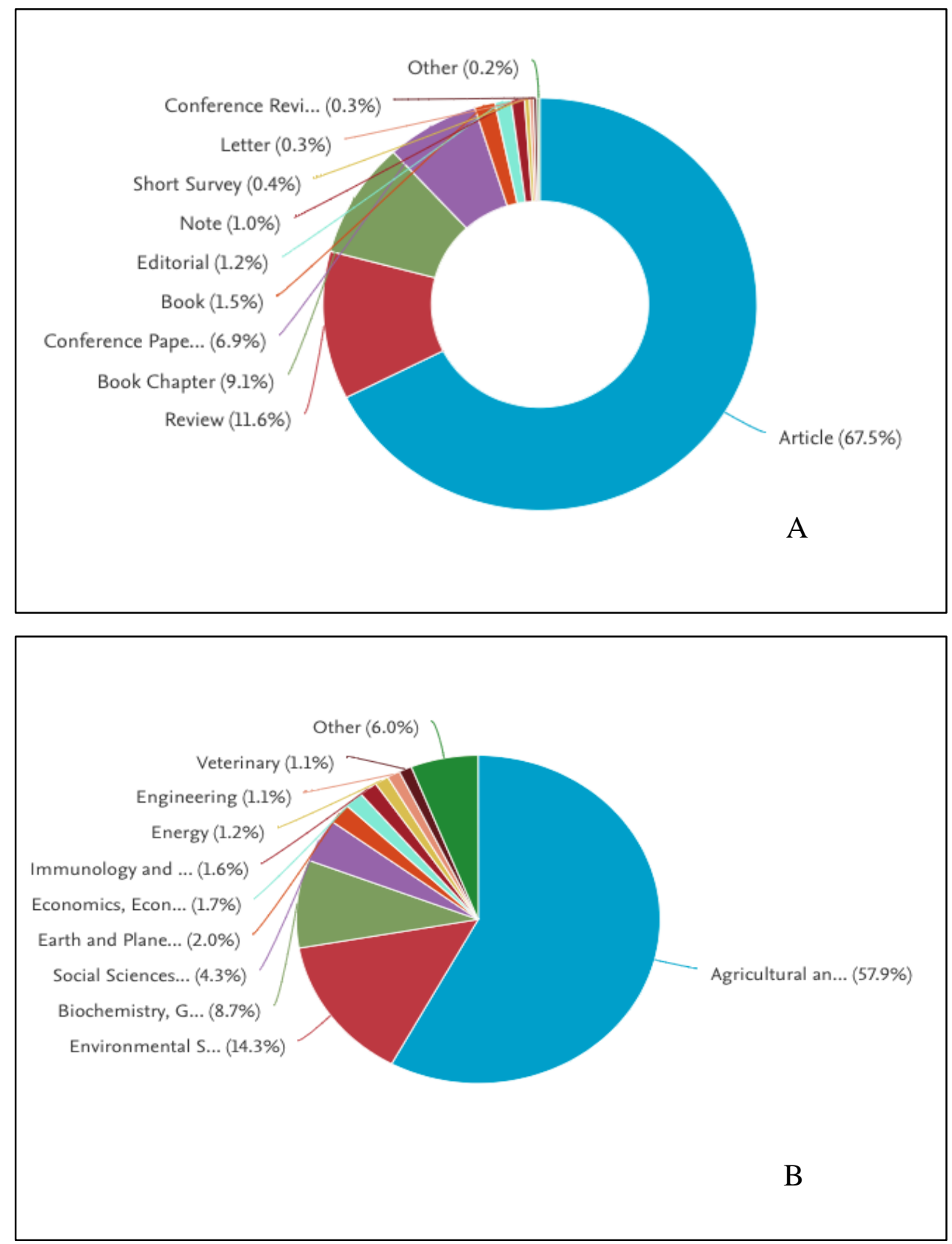
Figure 2: A. Pie-chart depicting the type of document and B. subject areas of research of the documents retrieved in the study

\subsection{Citation analysis}

It is understood that highly cited articles have a significant impact on the concerned subject worldwide. The citation analysis of retrieved documents showed 11334 citations with an average of 6.24 citations per document. Table 1 shows the top ten highly cited articles. The retrieved documents had a $h$-index of 40 with a range of citations from 0 to 264. The most cited (264 times) article was published in 2017 titled "Research priorities for harnessing plant microbiomes in sustainable agriculture" in the journal PLOS ONE. The review article promotes research on developing plant microbiome systems to enhance productivity. Five of the most cited articles were research articles and the other five were reviews. These articles discussed the aspects of precision agriculture, conservation biological control, organic farming, use of plant biostimulants, botanical insecticides, and biological control as measures for ensuring resilient and sustainable agriculture

Table 1: Top ten most cited articles under the theme of sustainable agriculture.

\begin{tabular}{|c|c|c|c|c|c|}
\hline S.No & $\begin{array}{c}\text { Publication } \\
\text { year }\end{array}$ & Document Title & Authors & Journal Title & $\begin{array}{c}\text { Total No. of } \\
\text { citations }\end{array}$ \\
\hline 1. & 2017 & $\begin{array}{l}\text { Research priorities for } \\
\text { harnessing plant } \\
\text { microbiomes in } \\
\text { sustainable agriculture }\end{array}$ & $\begin{array}{l}\text { Busby P.E., } \\
\text { Soman C., } \\
\text { Wagner M.R., } \\
\text { Friesen M.L., } \\
\text { Kremer J., } \\
\text { Bennett A., } \\
\text { Morsy M., } \\
\text { Eisen J.A., } \\
\text { Leach J.E., } \\
\text { Dangl J.L. }\end{array}$ & PLoS Biology & 264 \\
\hline 2. & 2018 & $\begin{array}{l}\text { Synergistic biostimulatory } \\
\text { action: Designing the next } \\
\text { generation of plant } \\
\text { biostimulants for } \\
\text { sustainable agriculture }\end{array}$ & $\begin{array}{l}\text { Rouphael Y., } \\
\text { Colla G. }\end{array}$ & $\begin{array}{l}\text { Frontiers in } \\
\text { Plant Science }\end{array}$ & 115 \\
\hline
\end{tabular}




\begin{tabular}{|c|c|c|c|c|c|}
\hline S.No & $\begin{array}{c}\text { Publication } \\
\text { year }\end{array}$ & Document Title & Authors & Journal Title & $\begin{array}{l}\text { Total No. of } \\
\text { citations }\end{array}$ \\
\hline 3. & 2017 & $\begin{array}{l}\text { Promoting sustainable } \\
\text { intensification in precision } \\
\text { agriculture: review of } \\
\text { decision support systems } \\
\text { development and } \\
\text { strategies }\end{array}$ & $\begin{array}{l}\text { Lindblom J., } \\
\text { Lundstrom C., } \\
\text { Ljung M., } \\
\text { Jonsson A. }\end{array}$ & $\begin{array}{l}\text { Precision } \\
\text { Agriculture }\end{array}$ & 109 \\
\hline 4. & 2017 & $\begin{array}{l}\text { Drought stress had a } \\
\text { predominant effect over } \\
\text { heat stress on three tomato } \\
\text { cultivars subjected to } \\
\text { combined stress }\end{array}$ & $\begin{array}{l}\text { Zhou R., Yu X., } \\
\text { Ottosen C.-O., } \\
\text { Rosenqvist E., } \\
\text { Zhao L., Wang } \\
\text { Y., Yu W., } \\
\text { Zhao T., Wu Z. }\end{array}$ & $\begin{array}{l}\text { BMC Plant } \\
\text { Biology }\end{array}$ & 108 \\
\hline 5. & 2018 & $\begin{array}{l}\text { Beyond agricultural } \\
\text { innovation systems? } \\
\text { Exploring an agricultural } \\
\text { innovation ecosystems } \\
\text { approach for niche design } \\
\text { and development in } \\
\text { sustainability transitions }\end{array}$ & $\begin{array}{l}\text { Pigford A.-A.E., } \\
\text { Hickey G.M., } \\
\text { Klerkx L. }\end{array}$ & $\begin{array}{l}\text { Agricultural } \\
\text { Systems }\end{array}$ & 93 \\
\hline 6. & 2017 & $\begin{array}{l}\text { Tomato facultative } \\
\text { parthenocarpy results from } \\
\text { SlAGAMOUS-LIKE } 6 \\
\text { loss of function }\end{array}$ & $\begin{array}{l}\text { Klap C., } \\
\text { Yeshayahou E., } \\
\text { Bolger A.M., } \\
\text { Arazi T., Gupta } \\
\text { S.K., Shabtai S., } \\
\text { Usadel B., Salts } \\
\text { Y., Barg R. }\end{array}$ & $\begin{array}{l}\text { Plant } \\
\text { Biotechnology } \\
\text { Journal }\end{array}$ & 90 \\
\hline 7. & 2017 & $\begin{array}{l}\text { A functional overview of } \\
\text { conservation biological } \\
\text { control }\end{array}$ & $\begin{array}{l}\text { Begg G.S., } \\
\text { Cook S.M., Dye } \\
\text { R., Ferrante M., } \\
\text { Franck P., } \\
\text { Lavigne C., } \\
\text { Lovei G.L., } \\
\text { Mansion- } \\
\text { Vaquie A., Pell } \\
\text { J.K., Petit S., } \\
\text { Quesada N., }\end{array}$ & $\begin{array}{l}\text { Crop } \\
\text { Protection }\end{array}$ & 83 \\
\hline
\end{tabular}




\begin{tabular}{|c|c|c|c|c|c|}
\hline S.No & $\begin{array}{c}\text { Publication } \\
\text { year }\end{array}$ & Document Title & Authors & Journal Title & $\begin{array}{c}\text { Total No. of } \\
\text { citations }\end{array}$ \\
\hline & & & $\begin{array}{l}\text { Ricci B., } \\
\text { Wratten S.D., } \\
\text { Birch A.N.E. }\end{array}$ & & \\
\hline 8. & 2018 & $\begin{array}{l}\text { Hydrological and } \\
\text { erosional impact and } \\
\text { farmer's perception on } \\
\text { catch crops and weeds in } \\
\text { citrus organic farming in } \\
\text { Canyoles river watershed, } \\
\text { Eastern Spain }\end{array}$ & $\begin{array}{l}\text { Cerda A., } \\
\text { Rodrigo- } \\
\text { Comino J., } \\
\text { Gimenez- } \\
\text { Morera A., } \\
\text { Keesstra S.D. }\end{array}$ & $\begin{array}{l}\text { Agriculture, } \\
\text { Ecosystems } \\
\text { and } \\
\text { Environment }\end{array}$ & 80 \\
\hline 9. & 2018 & $\begin{array}{l}\text { Titanium dioxide } \\
\text { nanoparticles improve } \\
\text { growth and enhance } \\
\text { tolerance of broad bean } \\
\text { plants under saline soil } \\
\text { conditions }\end{array}$ & $\begin{array}{l}\text { Abdel Latef } \\
\text { A.A.H., } \\
\text { Srivastava A.K., } \\
\text { El-sadek } \\
\text { M.S.A., } \\
\text { Kordrostami } \\
\text { M., Tran L.-S.P. }\end{array}$ & $\begin{array}{l}\text { Land } \\
\text { Degradation } \\
\text { and } \\
\text { Development }\end{array}$ & 76 \\
\hline 10. & 2019 & $\begin{array}{l}\text { Use of botanical } \\
\text { insecticides for sustainable } \\
\text { agriculture: Future } \\
\text { perspectives }\end{array}$ & $\begin{array}{l}\text { Campos E.V.R., } \\
\text { Proenca P.L.F., } \\
\text { Oliveira J.L., } \\
\text { Bakshi M., } \\
\text { Abhilash P.C., } \\
\text { Fraceto L.F. }\end{array}$ & $\begin{array}{l}\text { Ecological } \\
\text { Indicators }\end{array}$ & 74 \\
\hline
\end{tabular}

\subsection{Geographical distribution of retrieved documents}

Geographical distribution analysis was based on country of affiliation of the authors. Publications from authors belonging to 156 countries were retrieved (Figure 3). China, The United States of America, India, Italy, and Brazil were among the top five countries publishing highest number of articles in the period 2017-2021. China, with 285 documents, was the country with highest number of publications. 


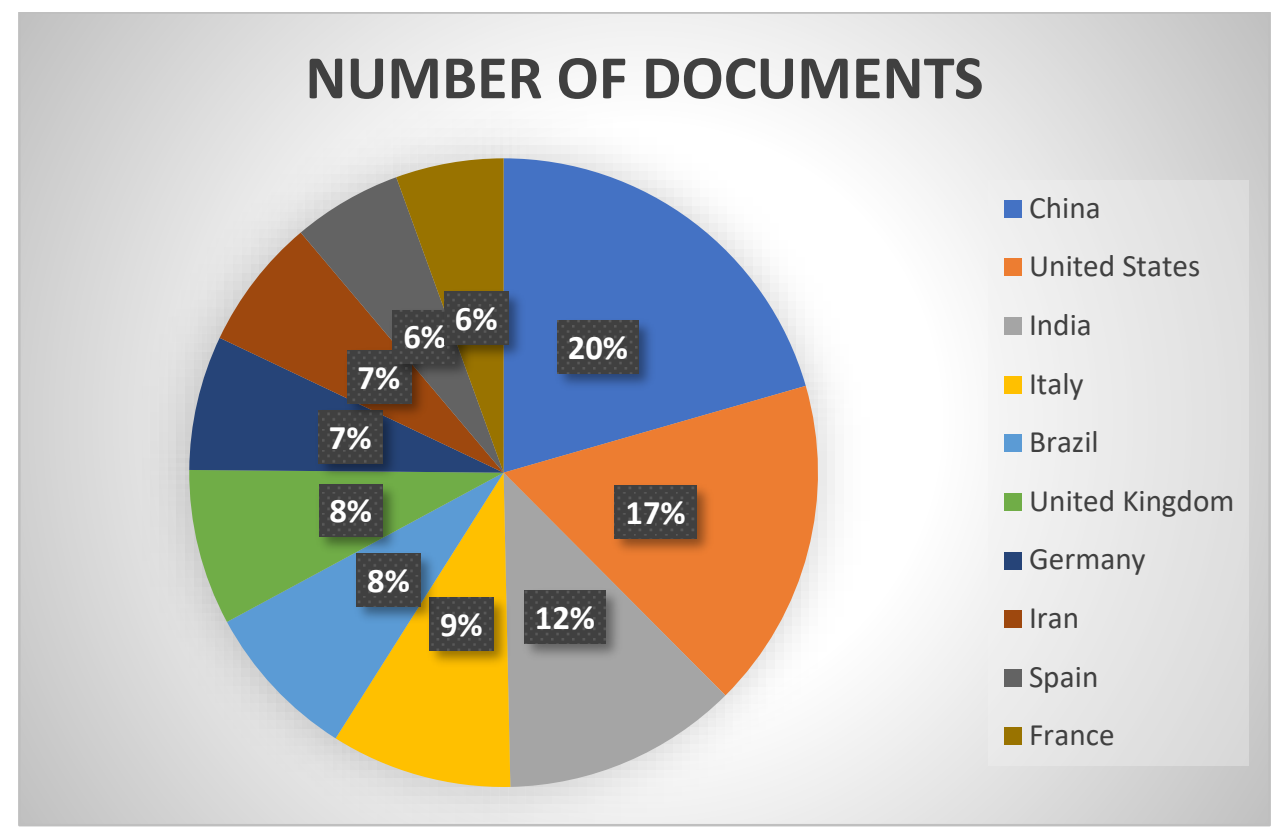

Figure 3: Top ten countries according to author affiliation

\subsection{Active authors, institutions, and organizations}

The identification of the most frequent authors helps to identify potential mentors and reviewers. A total of 160 authors were involved in publications retrieved during the defined period. Seven articles by Youssef Rouphael, the most active author in this field were cited 142 times. Five of the top ten authors (Table 2) belonged to Università degli Studi di Napoli Federico II, Naples, Italy. Data analyzed for most active institution/ organization showed that the Università degli Studi di Napoli Federico II, Naples, Italy had the highest number of documents (Table 3). Top funding agencies sponsoring research focusing on sustainable agriculture include National Natural Science Foundation, China, and European Commission in the period 2017 (Table 4). The maximum number of articles were published in the journal Agronomy followed by Frontiers in Plant Science (Table 5). The most cited article in the journal Agronomy was by Gao et al., (2020) and their study recommended the combined usage of bio and organic fertilizers for enhancing growth and reducing the usage of chemical fertilizers.

Table 2: Top ten active authors working in the field of sustainable agriculture

\begin{tabular}{|l|l|c|l|}
\hline Rank & Name & $\begin{array}{c}\text { Number of } \\
\text { articles }\end{array}$ & Affiliations \\
\hline
\end{tabular}




\begin{tabular}{|c|l|c|l|}
\hline 1 & Rouphael, Y. & 7 & $\begin{array}{l}\text { Università degli Studi di Napoli Federico II, } \\
\text { Naples, Italy }\end{array}$ \\
\hline 2 & Mori, M. & 6 & $\begin{array}{l}\text { Università degli Studi di Napoli Federico II, } \\
\text { Naples, Italy }\end{array}$ \\
\hline 3 & Abhilash, P.C. & 5 & Banaras Hindu University, India \\
\hline 4 & Babalola, O.O. & 5 & $\begin{array}{l}\text { North-West University, Potchefstroom, South } \\
\text { Africa }\end{array}$ \\
\hline 5 & Colla, G. & 5 & $\begin{array}{l}\text { Università degli Studi di Napoli Federico II, } \\
\text { Naples, Italy }\end{array}$ \\
\hline 6 & Di Mola, I. & 5 & $\begin{array}{l}\text { Università degli Studi di Napoli Federico II, } \\
\text { Naples, Italy }\end{array}$ \\
\hline 7 & El-Nakhel, C. & 5 & $\begin{array}{l}\text { Università degli Studi di Napoli Federico II, } \\
\text { Naples, Italy }\end{array}$ \\
\hline 8 & Fraceto, L.F. & 5 & $\begin{array}{l}\text { UNESP-Universidade Estadual Paulista, Sao } \\
\text { Paulo, Brazil }\end{array}$ \\
\hline 10 & Lee, I.J. & 5 & $\begin{array}{l}\text { Kyungpook National University, Daegu, South } \\
\text { Korea }\end{array}$ \\
\hline & & 5 & Gansu Agricultural University, Lanzhou, China \\
\hline
\end{tabular}

Table 3: Top ten active institutions involved in research in the field of sustainable agriculture

\begin{tabular}{|l|c|}
\hline Institution/Organization & Number of documents \\
\hline Chinese Academy of Sciences & 37 \\
\hline Wageningen University \& Research & 33 \\
\hline Chinese Academy of Agricultural Sciences & 33 \\
\hline Ministry of Agriculture of the People's Republic of China & 32 \\
\hline China Agricultural University & 26 \\
\hline Ministry of Education China & 26 \\
\hline Empresa Brasileira de Pesquisa Agropecuária - Embrapa & 25 \\
\hline University of Chinese Academy of Sciences & 24 \\
\hline INRAE & 22 \\
\hline Università degli Studi di Napoli Federico II & \\
\hline
\end{tabular}

Table 4: Details of top ten funding agencies sponsoring research in the theme of sustainable agriculture.

\begin{tabular}{|l|c|}
\hline Top ten funding agencies & No. of articles \\
\hline National Natural Science Foundation of China & 153 \\
\hline
\end{tabular}




\begin{tabular}{|c|c|}
\hline National Key Research and Development Program of China & 64 \\
\hline Conselho Nacional de Desenvolvimento Científico e Tecnológico & 60 \\
\hline European Commission & 59 \\
\hline Ministry of Science and Technology of the People's Republic of China & 42 \\
\hline U.S. Department of Agriculture & 33 \\
\hline Biotechnology and Biological Sciences Research Council & 32 \\
\hline Coordenação de Aperfeiçoamento de Pessoal de Nível Superior & 32 \\
\hline Minist $\tilde{A} \odot$ rio da Ci $\tilde{A}^{a}$ ncia, Tecnologia e Inova Ã $\tilde{A} £ o$ & 29 \\
\hline European Regional Development Fund & 25 \\
\hline
\end{tabular}

Table 5: Top ten journals publishing the most number of articles on sustainable agriculture

\begin{tabular}{|l|c|}
\hline Name of journal & Number of articles \\
\hline Agronomy & 84 \\
\hline Frontiers In Plant Science & 59 \\
\hline Agriculture Switzerland & 45 \\
\hline Agriculture Ecosystems And Environment & 36 \\
\hline Land Use Policy & 31 \\
\hline Plants & 30 \\
\hline International Journal of Agricultural Sustainability & 29 \\
\hline Applied Soil Ecology & 26 \\
\hline Frontiers In Sustainable Food Systems & 26 \\
\hline Agricultural Systems & 23 \\
\hline
\end{tabular}

\subsection{Bibliometric analysis of keywords}

Keywords from the 1674 publications were analyzed using VOSviewer. Keywords that occurred in the title and abstract fields, more than 50 times, were identified. Out of the 12248 keywords, 62 met the threshold. Frequent terms in the abstracts were mapped into three clusters (Figure 4). Cluster 1 (red colored; $n=24$ terms) had keywords such as sustainable agriculture (highest with 1566 occurrences), alternative agriculture, sustainable development, water conservation, water management, food security, environmental protection, environmental sustainability, climate change, conservation of natural resources, carbon footprint. The second cluster (green color, $n=21$ terms) with research theme highlighting factors affecting plant growth such as genetics, growth, development and aging, fertilizers, nutrients such as nitrogen and phosphorus, microbes. The third cluster 
(blue cluster, $\mathrm{n}=17$ terms) included terms like crop yield being affected by water supply, soil, fertilizer, irrigation, and use of agricultural robots, etc.

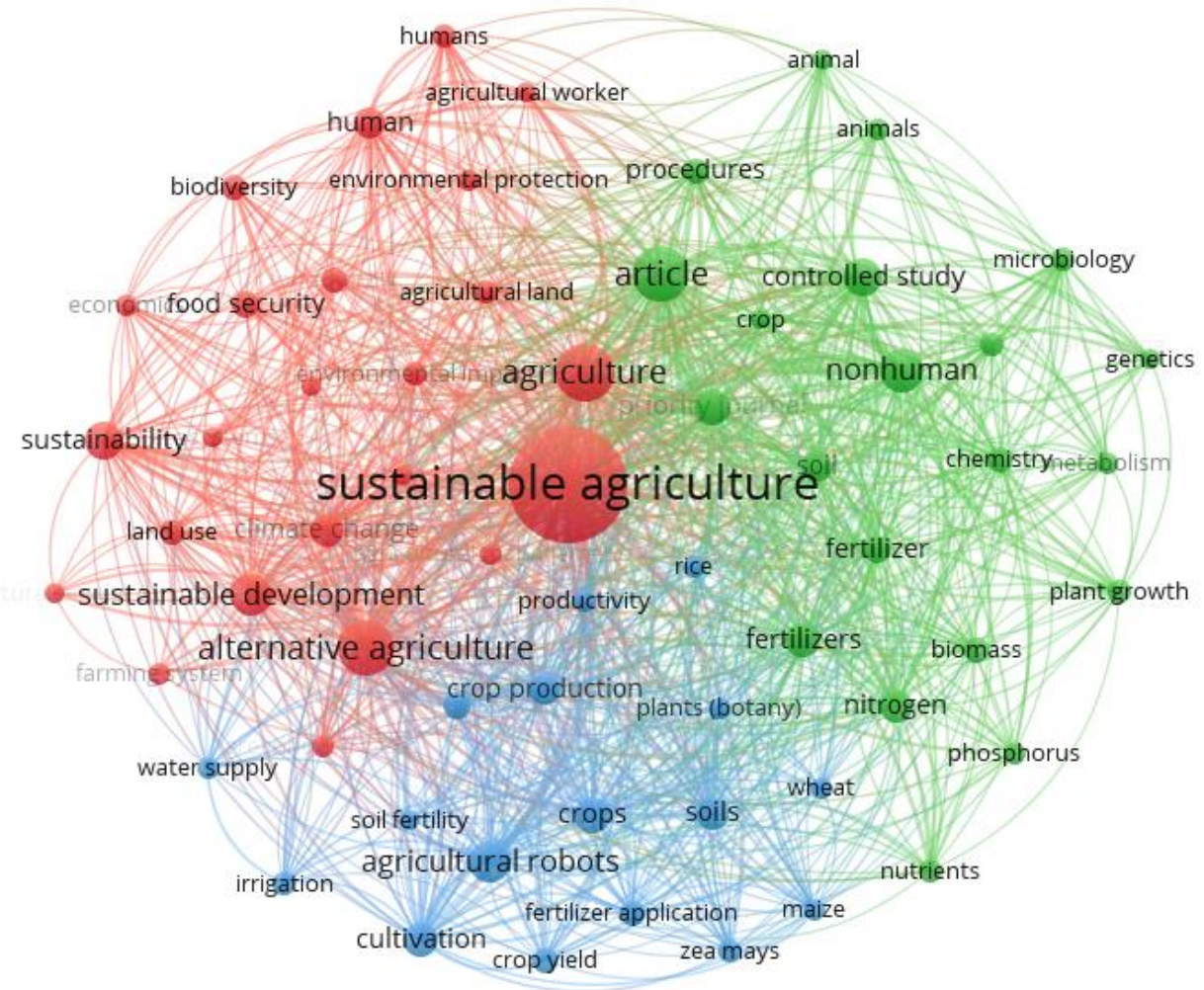

Figure 4: Network visualization based on co-occurrence of keywords. Each node represents a keyword. The size of the node represents the co-occurrence between keywords. Each of the three clusters represents a particular theme. Nodes in a cluster together have a common theme and their relationships with other nodes are represented by links.

\subsection{Bibliometric analysis of co-authorship}

Authors from 157 countries showing at least 10 documents and having a minimum of 10 citations each were selected. 48 met the threshold and these formed 5 clusters. China had the highest number of documents; 2274 citations with a total link strength of 149. The main collaborating partners of China were Canada and Ghana. The United States of America, with 237 documents and having 1982 citations, was in second place. The link strength for the US was 245, which was higher than China indicating higher collaborative nature of the projects. The main collaborators of the US were the South American nations of Brazil, Chile, Colombia, Argentina and Mexico. India was at third place with 164 documents, having 997 citations and 73 total link strength. Of the 5090 
organizations that were involved in research, collaborations was seen between 21 (with minimum threshold of three documents and three citations).

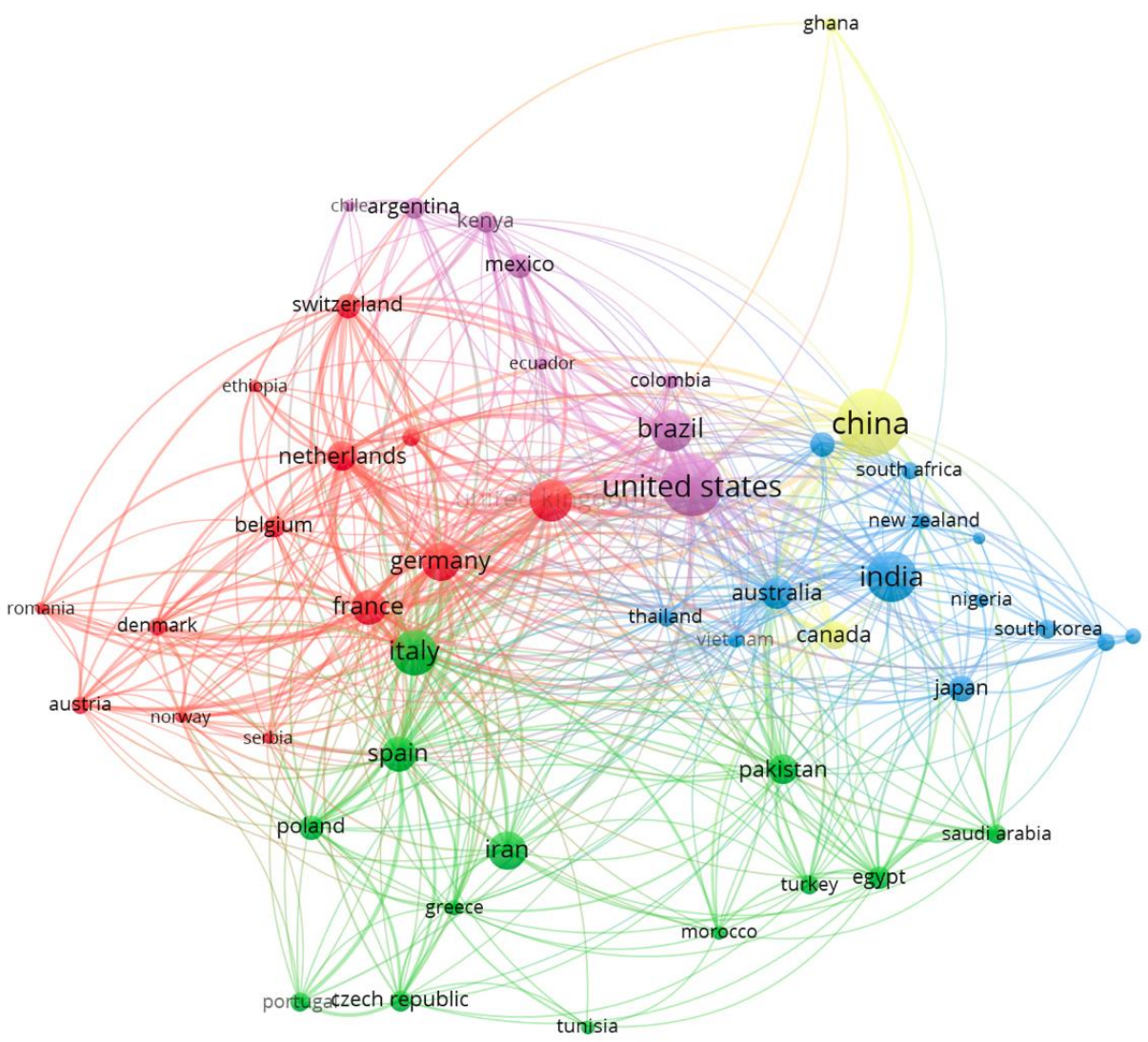

Figure 5: The network map of co-authorship based on affiliation of authors belonging to different countries

\subsection{Research themes}

To understand the main research approaches being pursued worldwide for achieving sustainable agriculture a keyword co-occurrence analysis was performed. Three closely related research themes were observed in the retrieved documents. Of particular interest was the research theme with a focus on sustainable agriculture. An interplay of issues such as climate change, food security, and food supply and linkage with sustainable development is highlighted in the analysis and these are the driving forces highlighted in research profiles. Soaring population and the interlinked need for ensuring food security has resulted in imposing heavy environmental pressure and changing land and water use (Bufebo \& Elias, 2021). Climate change, increasing water shortage, 
salinization of arable lands has driven researchers to explore the identification of alternative sustainable crops that are able to sustain growth amidst these stresses (Lin et al., 2021; Meco et al., 2019). Greenhouse gases are typical by-products of agriculture and known contributors to climate change. Case studies on carbon footprint assessment based on spatiotemporal pattern of carbon emission and carbon sequestration have been conducted to provide the base for adopting measures to improve carbon sink function and promote sustainable agriculture (Li \& Li, 2021; Qiao et al., 2019; G. Zhang et al., 2018). Climate-smart agriculture envisages a mechanism to ensure reducing dependability on environmental resources without affecting productivity (Rampa et al., 2020). Essential to reducing dependency on irrigation and ensuring judicious use of water resources is the research into water use efficiencies of crops (Brombin et al., 2020), identification of cultivars with lower water requirements (Wakchaure et al., 2021), adoption of technology such as adsorption based atmospheric water harvesting (Wang et al., 2021) and use of moisture adsorbent gels (Zhou et al., 2020). Additionally, microclimate modeling techniques to predict crop suitability and enable food production have been studied (Gardner et al., 2021). The use of agrochemicals to enhance crop yield endangers biodiversity and ecosystems (Malaj et al., 2020). Reduced fertilizer usage by replacing it with biofertilizers (Klaic et al., 2021; Tsachidou et al., 2021), ensuring a sustained release of nutrients using amendments such as biochar (Ullah et al., 2020) and nanoparticles (Avellan et al., 2021), soil organic carbon sequestration (Abera et al., 2021; Brombin et al., 2020; Mancinelli et al., 2020), crop rotation (Hirzel et al., 2021; Shrestha et al., 2020), intercropping (Shah et al., 2021), adoption of agroecological practices (Abbasi Surki et al., 2021; Rakotovao et al., 2021), utilization of crop residues for maintaining soil fertility (Berazneva et al., 2018; P. Zhang et al., 2021) are important for ensuring socio-ecological sustainability. Mathematical modeling to predict the vulnerability of crops to climatic factors enables the utilization of suitable strategies for mitigating effects on crop productivity (Anapalli et al., 2021). Unique strategies such as real-time monitoring of plant growth requirements (Lan et al., 2021), effective nutrient management strategies (Huang et al., 2021) to enhance sustainable use of resources thereby reducing ecological footprints are areas under investigation. Another key research area involved understanding the soilplant-microbe dynamics, that evolves because of interactions between specific plant 
phenological stage linked with specific nutrient applied and the particular microbial community that results (Pathan et al., 2020). Enhancement of plant growth using microbial consortia as biostimulants or biofertilizers (Amirnia et al., 2019; Avio et al., 2018; Castiglione et al., 2021; Kandasamy et al., 2021; Rouphael \& Colla, 2018) and replacing the use of pesticides with natural pest control agents such as root arbuscular mycorrhizal fungi (Deng et al., 2021), are key to improving productivity without compromising the soil biodiversity, have been investigated in detail. Addressing the concern of soil loss in hilly terrains with the adoption of erosion control measures such as bench terracing for growing crops, highlight the research focus with specific agroecological zones in mind (Rutebuka et al., 2021). Increasing awareness amongst farmers, changing their perception towards adoption of sustainable agricultural practices, has also been recognized (Hayran et al., 2018; Nguyen \& Drakou, 2021). A number of studies have highlighted the fact that the successful adoption of any strategy and generation of public support will only be useful if it is economically sustainable even for small farm households (Branca et al., 2021; Veluguri et al., 2021). Importantly, the specific strategy adopted would have to be sensitive to regional diversity with specific agro-climatic zones and farmer preferences and behaviors if it is to be successfully implemented (Orduño Torres et al., 2020). Studies have assessed the awareness and attitudes of farmers towards climate change, environmental and human repercussions of the current agricultural practices that need to be modified in order to address sustainable production (Gebska et al., 2020). The concerns and willingness of farmers to adopt newer strategies and technologies as a means for achieving higher economic gains has been ascertained (Roesch-Mcnally et al., 2020). Small scale projects envisaging the usage of community-supported farming and interlinking economic viability to such initiatives have shown promise even in regional contexts (Bisht, 2021; Lanker et al., 2020). A holistic approach that addresses economic, social, and environmental concerns will hold the key to developing viable sustainable agricultural systems (Daniel, 2020).

\subsection{Limitations}

The current study has focused on literature retrieved from the Scopus database. The counting of articles was based on affiliation. This limits the data since a document having several authors is counted only once whereas a document having two authors 
from different countries is counted once for each country. A bias could also have been created since self-citations were not excluded. Also, the search query was based on the theme of sustainable agriculture which has broad and complex scope making it difficult to ensure complete inclusion of literature on the topic. However, the authors have included suitable restrictions to keep the key area in focus.

\section{CONCLUSION}

Against the backdrop of climate change and increasing population, the challenge faced by scientists is how to enhance food production without compromising the environment. Currently, the research focus worldwide is on providing innovative solutions to meet these challenges. Sustainable agriculture management advocates measures to promote soil carbon sequestration, increasing soil fertility by modifying the microbiome, nutrient management using life-stage specific delivery, adoption of crops with higher resilience. The case studies offer the possibility for wider geographical adoption with suitable amendments ensuring a balance between productivity and ecosystem values. Future research needs to be collaborative and transdisciplinary and should focus on providing innovative agroecological solutions tailormade to address the regional issues while balancing economic productivity within sustainability for the present as well as future generations.

\section{CONFLICT OF INTEREST}

The authors declare that they have no conflict of interest.

\section{ACKNOWLEDGEMENT}

The support and encouragement provided by Principal, Maitreyi College and Centre of Research, Maitreyi College is gratefully acknowledged. We also express our gratitude to Dr Pardeep Rai, Librarian, Maitreyi College for providing access to e-resources and other technical support.

\section{FUNDING}

None

\section{REFERENCES}

Abbasi Surki, A., Nazari, M., Fallah, S., \& Iranipour, R. (2021). Improvement of the soil properties, nutrients, and carbon stocks in different cereal-legume agroforestry systems. International Journal of Environmental Science and Technology, 18(1), 123-130. https://doi.org/10.1007/s13762-020-02823-9 
Abera, W., Tamene, L., Abegaz, A., Hailu, H., Piikki, K., Söderström, M., Girvetz, E., \& Sommer, R. (2021). Estimating spatially distributed SOC sequestration potentials of sustainable land management practices in Ethiopia. Journal of $\begin{array}{lll}\text { Environmental } & \text { Management, } & \text { 286: }\end{array}$ https://doi.org/10.1016/j.jenvman.2021.112191

Amirnia, R., Ghiyasi, M., Siavash Moghaddam, S., Rahimi, A., Damalas, C. A., \& Heydarzadeh, S. (2019). Nitrogen-Fixing Soil Bacteria Plus Mycorrhizal Fungi Improve Seed Yield and Quality Traits of Lentil (Lens culinaris Medik). Journal of Soil Science and Plant Nutrition, 19(3), 592-602. https://doi.org/10.1007/s42729-019-00058-3

Anapalli, S. S., Pinnamaneni, S. R., Fisher, D. K., \& Reddy, K. N. (2021). Vulnerabilities of irrigated and rainfed corn to climate change in a humid climate in the Lower Mississippi Delta. Climatic Change, 164(1-2). https://doi.org/10.1007/s10584-021-02999-0

Avellan, A., Yun, J., Morais, B. P., Clement, E. T., Rodrigues, S. M., \& Lowry, G. V. (2021). Critical Review: Role of Inorganic Nanoparticle Properties on Their Foliar Uptake and in Planta Translocation. Environmental Science and Technology. https://doi.org/10.1021/acs.est.1c00178

Avio, L., Turrini, A., Giovannetti, M., \& Sbrana, C. (2018). Designing the ideotype mycorrhizal symbionts for the production of healthy food. Frontiers in Plant Science, 9. https://doi.org/10.3389/fpls.2018.01089

Baas, J., Schotten, M., Plume, A., Côté, G., \& Karimi, R. (2020). Scopus as a curated, high-quality bibliometric data source for academic research in quantitative science studies. Quantitative Science Studies, 1(1), 377-386. https://doi.org/10.1162/qss_a_00019

Berazneva, J., Lee, D. R., Place, F., \& Jakubson, G. (2018). Allocation and Valuation of Smallholder Maize Residues in Western Kenya. Ecological Economics, 152, 172-182. https://doi.org/10.1016/j.ecolecon.2018.05.024

Bisht, I. S. (2021). Agri-food system dynamics of small-holder hill farming communities of Uttarakhand in north-western India: Socio-economic and policy considerations for sustainable development. Agroecology and Sustainable Food Systems, 45(3), 417-449. https://doi.org/10.1080/21683565.2020.1825585 
Branca, G., Arslan, A., Paolantonio, A., Grewer, U., Cattaneo, A., Cavatassi, R., Lipper, L., Hillier, J., \& Vetter, S. (2021). Assessing the economic and mitigation benefits of climate-smart agriculture and its implications for political economy: A case study in Southern Africa. Journal of Cleaner Production, 285. https://doi.org/10.1016/j.jclepro.2020.125161

Brombin, V., Mistri, E., Feudis, M. D., Forti, C., Salani, G. M., Natali, C., Falsone, G., Antisari, L. V., \& Bianchini, G. (2020). Soil carbon investigation in three pedoclimatic and agronomic settings of northern Italy. Sustainability (Switzerland), 12(24), 1-19. https://doi.org/10.3390/su122410539

Bufebo, B., \& Elias, E. (2021). Land Use/Land Cover Change and Its Driving Forces in Shenkolla Watershed, South Central Ethiopia. Scientific World Journal, 2021. https://doi.org/10.1155/2021/9470918

Bunders, J. (1988). Appropriate biotechnology for sustainable agriculture in developing countries*1. Trends in Biotechnology, 6(8), 173-180. https://doi.org/10.1016/0167-7799(88)90042-X

Castiglione, S., Oliva, G., Vigliotta, G., Novello, G., Gamalero, E., Lingua, G., Cicatelli, A., \& Guarino, F. (2021). Effects of compost amendment on glycophyte and halophyte crops grown on saline soils: Isolation and characterization of rhizobacteria with plant growth promoting features and high salt resistance. Applied Sciences (Switzerland), 11(5), 1-15. https://doi.org/10.3390/app11052125

Daniel, E. C. (2020). Towards sustainable organic farming systems. Sustainability (Switzerland), 12(23), 1-5. https://doi.org/10.3390/su12239832

Deng, A. N., Luo, J. H., Su, C. L., Wu, X. F., \& Zhao, M. (2021). Reduced inorganic fertiliser in combination with an alkaline humic acid fertiliser amendment on acid growth media properties and cherry tomato growth. New Zealand Journal of Crop and Horticultural Science, 49(2-3), 225-242. https://doi.org/10.1080/01140671.2021.1887294

Donthu, N., Kumar, S., Mukherjee, D., Pandey, N., \& Lim, W. M. (2021). How to conduct a bibliometric analysis: An overview and guidelines. Journal of Business Research, 133, 285-296. https://doi.org/10.1016/j.jbusres.2021.04.070 
Edwards, C. A. (1987). The concept of integrated systems in lower input/sustainable agriculture. American Journal of Alternative Agriculture, 2(4), 148-152. https://doi.org/10.1017/S0889189300009255

Fróna, D., Szenderák, J., \& Harangi-Rákos, M. (2019). The Challenge of Feeding the World. Sustainability, 11(20), 5816. https://doi.org/10.3390/su11205816

Gao, C., El-Sawah, A. M., Ismail Ali, D. F., Hamoud, Y. A., Shaghaleh, H., \& Sheteiwy, M. S. (2020). The integration of bio and organic fertilizers improve plant growth, grain yield, quality and metabolism of hybrid maize (Zea mays L.). Agronomy, 10(3). https://doi.org/10.3390/agronomy10030319

Gardner, A. S., Maclean, I. M. D., Gaston, K. J., \& Bütikofer, L. (2021). Forecasting future crop suitability with microclimate data. Agricultural Systems, 190. https://doi.org/10.1016/j.agsy.2021.103084

Gebska, M., Grontkowska, A., Swiderek, W., \& Golebiewska, B. (2020). Farmer awareness and implementation of sustainable agriculture practices in different types of farms in Poland. Sustainability (Switzerland), 12(19), 1-17. https://doi.org/10.3390/su12198022

Hallberg, G. R. (1987). Agricultural chemicals in ground water: Extent and implications. American Journal of Alternative Agriculture, 2(1), 3-15. https://doi.org/10.1017/S0889189300001405

Hayran, S., Gul, A., \& Saridas, M. A. (2018). Farmers' sustainable agriculture perception in Turkey: The case of Mersin province. New Medit, 17(3), 69-78. https://doi.org/10.30682/nm1803f

Hirzel, J., Undurraga, P., León, L., Carrasco, J., González, J., \& Matus, I. (2021). Bean production and soil chemical properties are affected by the application of different residue levels from three crop rotations. Archives of Agronomy and Soil Science. https://doi.org/10.1080/03650340.2021.1878155

Huang, S., Ding, W., Jia, L., Hou, Y., Zhang, J., Xu, X., Xu, R., Ullah, S., Liu, Y., \& He, P. (2021). Cutting environmental footprints of maize systems in China through Nutrient Expert management. Journal of Environmental Management, 282. https://doi.org/10.1016/j.jenvman.2021.111956

Kandasamy, S., Weerasuriya, N., Subramanian, G., Thorn, R. G., Patterson, G., Ali, S., \& Lazarovits, G. (2021). Disentangling the Association of Corn Root 
Mycobiome With Plant Productivity and the Importance of Soil Physicochemical Balance in Shaping Their Relationship. Frontiers in Sustainable Food Systems, 5. https://doi.org/10.3389/fsufs.2021.617332

Klaic, R., Guimarães, G. G. F., Giroto, A. S., Bernardi, A. C. C., Zangirolami, T. C., Ribeiro, C., \& Farinas, C. S. (2021). Synergy of Aspergillus niger and Components in Biofertilizer Composites Increases the Availability of Nutrients to Plants. Current Microbiology, 78(4), 1529-1542. https://doi.org/10.1007/ $\underline{\text { s00284-021-02406-y }}$

Knickel, K., Ashkenazy, A., Chebach, T. C., \& Parrot, N. (2017). Agricultural modernization and sustainable agriculture: Contradictions and complementarities. International Journal of Agricultural Sustainability, 15(5), 575-592. https://doi.org/10.1080/14735903.2017.1373464

Lan, L., Xiong, J., Gao, D., Li, Y., Chen, J., Lv, J., Ping, J., Ying, Y., \& Lee, P. S. (2021). Breathable Nanogenerators for an On-Plant Self-Powered Sustainable Agriculture System. ACS Nano, 15(3), 5307-5315. https://doi.org/10.1021/ $\underline{\text { acsnano.0c10817 }}$

Lanker, M., Bell, M., \& Picasso, V. D. (2020). Farmer perspectives and experiences introducing the novel perennial grain Kernza intermediate wheatgrass in the US Midwest. Renewable Agriculture and Food Systems, 35(6), 653-662. https://doi.org/10.1017/S1742170519000310

Li, C., \& Li, S. (2021). Energy budget and carbon footprint in a wheat and maize system under ridge furrow strategy in dry semi humid areas. Scientific Reports, 11(1), 9367. https://doi.org/10.1038/s41598-021-88717-3

Lin, R., Guo, L., Zhang, S., Han, L., \& Xiao, K. (2021). Agronomic and Physiological Evaluation of Wheat Cultivars under Deficit Irrigation Condition. International Journal of Agriculture and Biology, 25(5), 929-936. https://doi.org/10.17957/IJAB/15.1748

Lv, W., Zhao, X., Wu, P., Lv, J., \& He, H. (2021). A Scientometric Analysis of Worldwide Intercropping Research Based on Web of Science Database between 1992 and 2020. Sustainability, 13(5), 2430. https://doi.org/10.3390/su13052430 
Malaj, E., Freistadt, L., \& Morrissey, C. A. (2020). Spatio-Temporal Patterns of Crops and Agrochemicals in Canada Over 35 Years. Frontiers in Environmental Science, 8. https://doi.org/10.3389/fenvs.2020.556452

Mancinelli, R., Marinari, S., Allam, M., \& Radicetti, E. (2020). Potential role of fertilizer sources and soil tillage practices to mitigate soil $\mathrm{CO} 2$ emissions in mediterranean potato production systems. Sustainability (Switzerland), 12(20), 1-14. https://doi.org/10.3390/su12208543

Meco, V., Egea, I., Albaladejo, I., Campos, J. F., Morales, B., Ortíz-Atienza, A., Capel, C., Angosto, T., Bolarín, M. C., \& Flores, F. B. (2019). Identification and characterisation of the tomato parthenocarpic mutant high fruit set under stress (hfs) exhibiting high productivity under heat and salt stress. Annals of Applied Biology, 174(2), 166-178. https://doi.org/10.1111/aab.12486

Mockshell, J., \& Kamanda, J. (2018). Beyond the agroecological and sustainable agricultural intensification debate: Is blended sustainability the way forward? International Journal of Agricultural Sustainability, 16(2), 127-149. https://doi.org/10.1080/14735903.2018.1448047

Nguyen, N., \& Drakou, E. G. (2021). Farmers intention to adopt sustainable agriculture hinges on climate awareness: The case of Vietnamese coffee. Journal of Cleaner Production, 303. https://doi.org/10.1016/j.jclepro.2021.126828

Orduño Torres, M. A., Kallas, Z., \& Ornelas Herrera, S. I. (2020). Farmers' environmental perceptions and preferences regarding climate change adaptation and mitigation actions; towards a sustainable agricultural system in México. Land Use Policy, 99. https://doi.org/10.1016/j.landusepol.2020.105031

Pan, X., Lv, J., Dyck, M., \& He, H. (2021). Bibliometric Analysis of Soil Nutrient Research between 1992 and 2020. Agriculture, 11(3), 223. https://doi.org/10.3390/agriculture11030223

Pathan, S. I., Scibetta, S., Grassi, C., Pietramellara, G., Orlandini, S., Ceccherini, M. T., \& Napoli, M. (2020). Response of soil bacterial community to application of organic and inorganic phosphate based fertilizers under vicia faba L. Cultivation at two different phenological stages. Sustainability (Switzerland), 12(22), 1-23. https://doi.org/10.3390/su12229706 
Peter, B. G., Messina, J. P., Lin, Z., \& Snapp, S. S. (2020). Crop climate suitability mapping on the cloud: A geovisualization application for sustainable agriculture. Scientific Reports, 10(1), 15487. https://doi.org/10.1038/s41598020-72384-X

Qiao, H., Zheng, F., Jiang, H., \& Dong, K. (2019). The greenhouse effect of the agriculture-economic growth-renewable energy nexus: Evidence from G20 countries. Science of The Total Environment, 671, 722-731. https://doi.org/10.1016/j.scitotenv.2019.03.336

Rakotovao, N. H., Chevallier, T., Chapuis-Lardy, L., Deffontaines, S., Mathé, S., Ramarofidy, M. A., Rakotoniamonjy, T. H., Lepage, A., Masso, C., Albrecht, A., \& Razafimbelo, T. M. (2021). Impacts on greenhouse gas balance and rural economy after agroecology development in Itasy Madagascar. Journal of Cleaner Production, 291. https://doi.org/10.1016/j.jclepro.2020.125220

Rampa, A., Gadanakis, Y., \& Rose, G. (2020). Land reform in the era of global warming - Can land reforms help agriculture be climate-smart? Land, 9(12), 124. https://doi.org/10.3390/land9120471

Rocchi, L., Boggia, A., \& Paolotti, L. (2020). Sustainable Agricultural Systems: A Bibliometrics Analysis of Ecological Modernization Approach. Sustainability, 12(22), 9635. https://doi.org/10.3390/su12229635

Roesch-Mcnally, G., Garrett, A., \& Fery, M. (2020). Assessing perceptions of climate risk and adaptation among small farmers in Oregon's Willamette Valley. Renewable Agriculture and Food Systems, 35(6), 626-630. https://doi.org/10.1017/S1742170519000267

Rouphael, Y., \& Colla, G. (2018). Synergistic biostimulatory action: Designing the next generation of plant biostimulants for sustainable agriculture. Frontiers in Plant Science, 871. https://doi.org/10.3389/fpls.2018.01655

Rutebuka, J., Munyeshuli Uwimanzi, A., Nkundwakazi, O., Mbarushimana Kagabo, D., Mbonigaba, J. J. M., Vermeir, P., \& Verdoodt, A. (2021). Effectiveness of terracing techniques for controlling soil erosion by water in Rwanda. Journal of Environmental Management, 277, 111369. https://doi.org/10.1016/j.jenvman. $\underline{2020.111369}$ 
Shah, T. M., Tasawwar, S., Bhat, M. A., \& Otterpohl, R. (2021). Intercropping in rice farming under the system of rice intensification-An agroecological strategy for weed control, better yield, increased returns, and social-ecological sustainability. Agronomy, 11(5), 11051010. https://doi.org/10.3390/agronomy11051010

Shrestha, P., Karim, R. A., Sieverding, H. L., Archer, D. W., Kumar, S., Nleya, T., Graham, C. J., \& Stone, J. J. (2020). Life cycle assessment of wheat production and wheat-based crop rotations. Journal of Environmental Quality, 49(6), 15151529. https://doi.org/10.1002/jeq2.20158

Sweileh, W. M. (2020). Bibliometric analysis of peer-reviewed literature on food security in the context of climate change from 1980 to 2019. Agriculture \& Food Security, 9(1), 11. https://doi.org/10.1186/s40066-020-00266-6

Tian, Z., Wang, J.-W., Li, J., \& Han, B. (2021). Designing future crops: Challenges and strategies for sustainable agriculture. Plant Journal, 105(5), 1165-1178. https://doi.org/10.1111/tpj.15107

Tsachidou, B., Hissler, C., Noo, A. Ï., Lemaigre, S., Daigneux, B., Gennen, J., Pacaud, S., George, I. F., \& Delfosse, P. (2021). Biogas residues in the battle for terrestrial carbon sequestration: A comparative decomposition study in the grassland soils of the Greater Region. Journal of Environmental Management, 286, 112272. https://doi.org/10.1016/j.jenvman.2021.112272

Ullah, N., Ditta, A., Khalid, A., Mehmood, S., Rizwan, M. S., Ashraf, M., Mubeen, F., Imtiaz, M., \& Iqbal, M. M. (2020). Integrated Effect of Algal Biochar and Plant Growth Promoting Rhizobacteria on Physiology and Growth of Maize Under Deficit Irrigations. Journal of Soil Science and Plant Nutrition, 20(2), 346-356. https://doi.org/10.1007/s42729-019-00112-0

Veluguri, D., Bump, J. B., Venkateshmurthy, N. S., Mohan, S., Pulugurtha, K. T., \& Jaacks, L. M. (2021). Political analysis of the adoption of the Zero-Budget natural farming program in Andhra Pradesh, India. Agroecology and Sustainable Food Systems, 45(6), 907-930. https://doi.org/10.1080/21683565. $\underline{2021.1901832}$

Wakchaure, G. C., Minhas, P. S., Kumar, S., Khapte, P. S., Meena, K. K., Rane, J., \& Pathak, H. (2021). Quantification of water stress impacts on canopy traits, yield, quality and water productivity of onion (Allium cepa L.) cultivars in a shallow 
basaltic soil of water scarce zone. Agricultural Water Management, 249, 106824. https://doi.org/10.1016/j.agwat.2021.106824

Wang, C., Zou, H., \& Wang, R. (2021). Sustainable Agriculture and Desert Bloom via Atmospheric Water Harvesting [空气取水实现可持续农业和沙漠绿化]. Shanghai Jiaotong Daxue Xuebao/Journal of Shanghai Jiaotong University, 55, 88-90. https://doi.org/10.16183/j.cnki.jsjtu.2021.S1.015

Zhang, G., Wang, X., Zhang, L., Xiong, K., Zheng, C., Lu, F., Zhao, H., Zheng, H., \& Ouyang, Z. (2018). Carbon and water footprints of major cereal crops production in China. Journal of Cleaner Production, 194, 613-623. https://doi.org/10.1016/j.jclepro.2018.05.024

Zhang, P., He, Y., Ren, T., Wang, Y., Liu, C., Li, N., \& Li, L. (2021). The crop residue removal threshold ensures sustainable agriculture in the purple soil region of Sichuan, China. Sustainability (Switzerland), 13(7), 1-16. https://doi.org/10.3390/su13073799

Zhou, X., Zhang, P., Zhao, F., \& Yu, G. (2020). Super moisture absorbent gels for sustainable agriculture via atmospheric water irrigation. ACS Materials Letters, 2(11), 1419-1422. https://doi.org/10.1021/acsmaterialslett.0c00439

How to cite this article: Sharma, R., \& Sisodia, R. (2021). Bibliometric Analysis of Peer Reviewed Literature on Sustainable Agriculture Research - Challenges and Prospects. Vantage: Journal of Thematic Analysis, 2(2):

DOI: https://doi.org/10.52253/vjta.2021.v02i02.03

(C) The Author(s) 2021.

This work is licensed under a Creative Commons Attribution 4.0 International License which permits its use, distribution and reproduction in any medium, provided the original work is cited. 